\title{
Chemical Compounds of Malacca Leaf (Phyllanthus emblica) after Triple Extraction with N-Hexane, Ethyl Acetate, and Ethanol
}

\author{
Nuzul Asmilia $\mathbb{C D}^{1,2}$ Yudha Fahrimal, ${ }^{3}$ Mahdi Abrar, ${ }^{4}$ and Rinidar Rinidar ${ }^{5}$ \\ ${ }^{1}$ Graduate School of Mathematics and Applied Sciences, Universitas Syiah Kuala, Banda Aceh 23111, Indonesia \\ ${ }^{2}$ Clinical Laboratory, Faculty of Veterinary Medicine, Universitas Syiah Kuala, Banda Aceh 23111, Indonesia \\ ${ }^{3}$ Parasitology Laboratory, Faculty of Veterinary Medicine, Universitas Syiah Kuala, Banda Aceh 23111, Indonesia \\ ${ }^{4}$ Microbiology Laboratory, Faculty of Veterinary Medicine, Universitas Syiah Kuala, Banda Aceh 23111, Indonesia \\ ${ }^{5}$ Pharmacology Laboratory, Faculty of Veterinary Medicine, Universitas Syiah Kuala, Banda Aceh 23111, Indonesia \\ Correspondence should be addressed to Nuzul Asmilia; nuzulasmilia@unsyiah.ac.id
}

Received 11 December 2019; Accepted 8 February 2020; Published 27 April 2020

Academic Editor: Najeh Rekik

Copyright ( 92020 Nuzul Asmilia et al. This is an open access article distributed under the Creative Commons Attribution License, which permits unrestricted use, distribution, and reproduction in any medium, provided the original work is properly cited.

\begin{abstract}
Malacca (Phyllanthus emblica) is one of the plants that is often by the community in the Aceh Besar district of Indonesia as a traditional medicine for the treatment of various diseases such as antimicrobial, antibacterial, antifungals, antivirals, antimutagenic, antimalaria, and antiallergic. This research was conducted to analyze the content of chemical compounds in the ethanol extract of the Malacca leaf (EEDM) using a gas chromatography-mass spectrophotometer (GC-MS). Malacca leaves were extracted by the maceration method using $n$-hexane, ethyl acetate, and ethanol. The GC-MS analysis showed EEDM contained 22 chemical compounds. The highest chemical content of EEDM is octadecanoic acid reaching 22.93\%, 9,12-octadecanoic acid 14.99\%, octadecanoic acid 7.59\%, 9-hexadecenoic acid 6.17\%, octadecanoic acid 5.95\%, octadecanal 5.59\%, 9,12-octadecanoic acid $5.06 \%$, 3-eicosyne 4.75\%, 1-hexadecenoic acid 4.08\%, 11-tetradecen-1-ol 2.92\%, 2-furanmethanol 2.83\%, delta-guaiene $2.43 \%$, cyclohexane $2.13 \%$, hexadecanoic acid $1.99 \%$, sativen $1.87 \%$, octadecanoic acid $1.52 \%$, $1 \mathrm{H}$-cyclopropaanaphthalene $1.40 \%$, tetradecanoic acid 1.40\%, 3,7,11-tridecatrienenitrile $1.20 \%$, caryophellene $1.11 \%, 2 \mathrm{H}$-pyran $1.07 \%$, and trans-caryophellene $1.03 \%$. This study clearly shows the presence of fatty acids which play a major role in the efficacy of these traditional medicines particularly as antioxidant and antimalarial.
\end{abstract}

\section{Introduction}

Malacca (Phyllanthus emblica) is one of the plants that is often used by the community in the Aceh Besar district of Indonesia as a traditional medicine for the treatment of various diseases. Phyllanthus emblica in Indonesia is known as the kimalaka [1]. The plant is also called "bak rem" (Acehnese), balakka in North Sumatra, metengo in Ternate [2], and kemloko in Java [3]. In English, these plants are referred as gooseberry Indians [4], and India is known by various names such as aonla, nelli, amla, amlika, dhotri, emblica, and usuri [5] In Malaysia, it is called diaper melaka, in German called amla [6], and in Thailand called ma-khampom [7].
Malacca is widespread in most tropical countries and subtropical countries and is native to South and Southeast Asia [8]. This plant belongs to the family Euphorbiaceae which is widely distributed and grows wild in India, Sri Lanka, Pakistan, Uzbekistan, China, Indonesia, Malaysia, and Thailand. Malacca can grow on the hillside with a height of 200 meters and can be cultivated $[9,10]$. The identification of Phyllanthus emblica Linn., has a very large genus of around 550 to 750 species which are divided into 10 to 11 subgenera [11].

Numerous studies have been done on the Malacca plant which reported that the Malacca plant has a potency as chemoprotective and antioxidant [6], analgesic, antipyretic $[12]$, antitumor $[13,14]$, anti-inflammation $[15,16]$, able to 


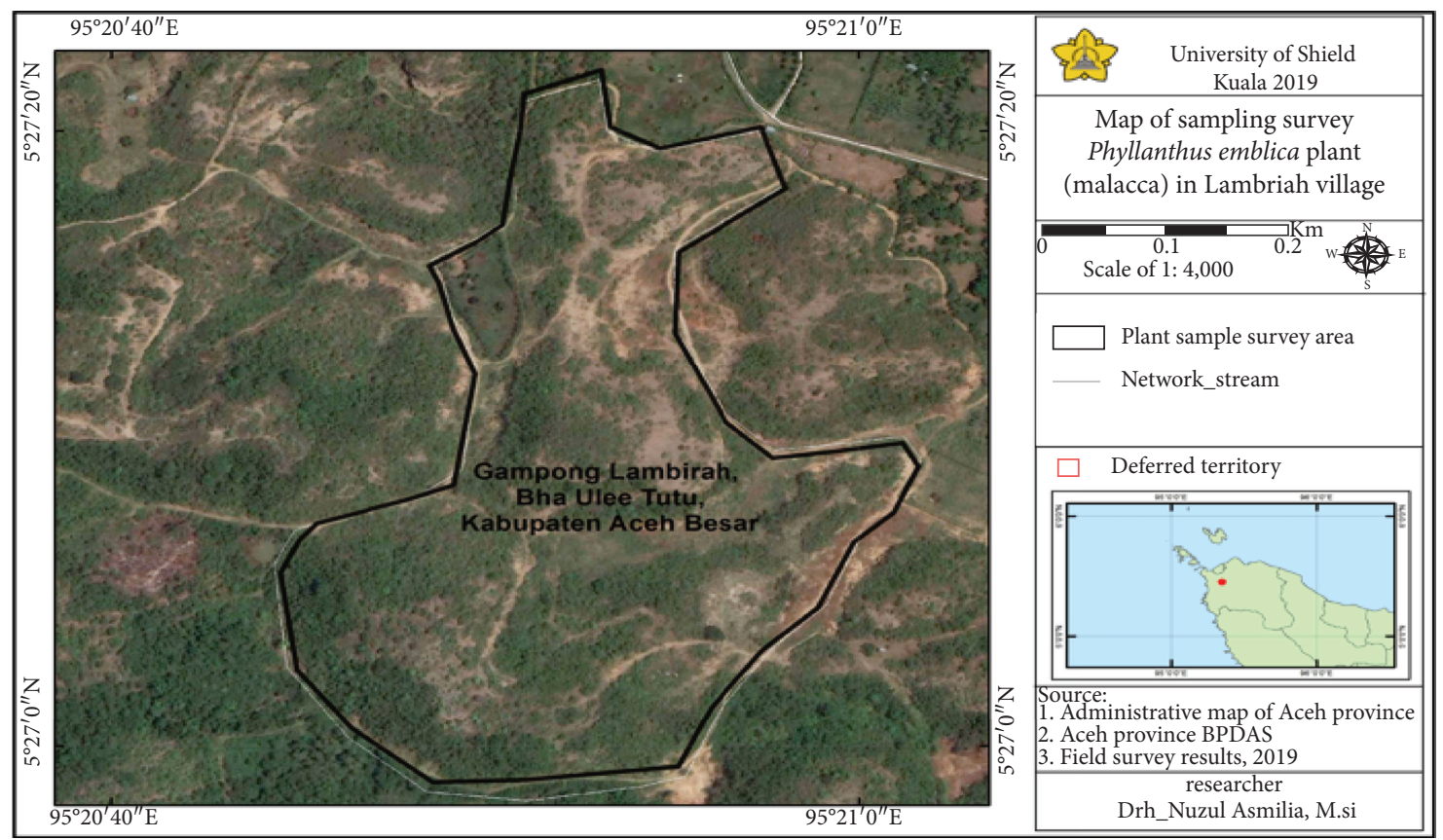

FIgURE 1: Sampling location.

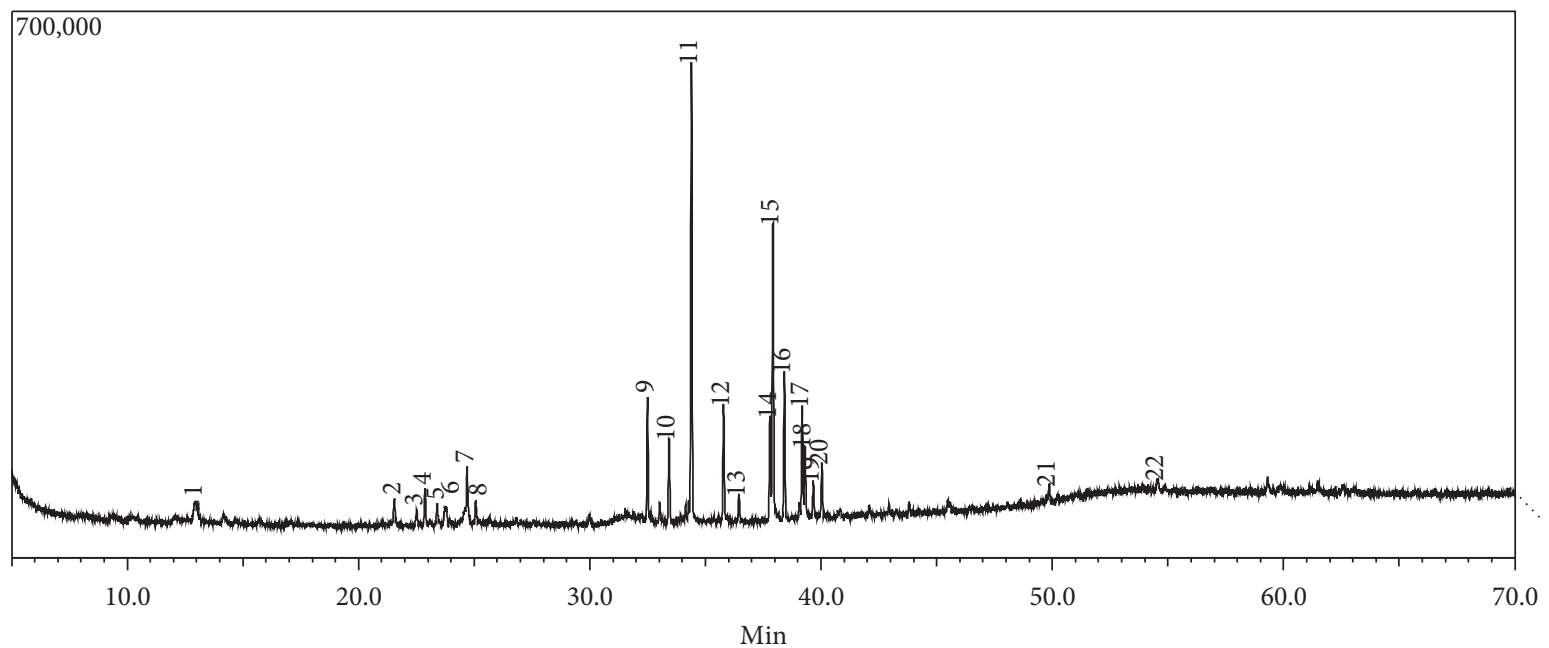

FIgURE 2: GC-MS chromatogram of the ethanolic extract of the leaves of Phyllanthus emblica leaves.

decrease blood sugar level [17], antiviral, antimutagenic, and antiallergic [18], antimicrobial, and antibacterial antifungals $[19,20]$. Malar and Mary [21] proved that the fruit of Malacca can appear to be able to repair liver damage, and Asmilia et al. [22] reported that the ethanolic extract of Malacca leaves has a higher inhibition level on Plasmodium falciparum growth compared to ethyl acetate and n-hexane extract of Malacca leaves. Deepak and Gopal [23] found terpenes, phytosterols, and terpenoids in ethyl acetate extracts from the bark of Phyllanthus emblica. So far, there has been no report on the content of the chemical compounds of Malacca leaves triple extracted using $n$-hexane, ethyl acetate, and ethanol solution. Therefore, analysis and determination of the content of the chemical compounds of Malacca leaves need to be done. This study was conducted to determine the content and identification of the ethanol extract compound of Malacca leaves macerated in three stages using $n$-hexane, ethyl acetate, and ethanol.

\section{Materials and Methods}

2.1. Malacca Leaf Samples. Malacca leaf samples were collected from Malacca plants that grew in the Blang Thutu area, Lambirah Village, Aceh Besar, Aceh, in April 2018. Identification of plants was conducted at the Herbarium Biology of Faculty of Mathematics and Natural Sciences, Syiah Kuala University, and identified as the Phyllanthus emblica Linn. 
Table 1: Phytocomponents identified from the ethanol extract of Phyllanthus emblica leaves.

\begin{tabular}{|c|c|c|c|c|c|}
\hline Peak no. & Retention time & Name of the compound & Molecular formula & Mol weight & Peak area \% \\
\hline 1 & 12,949 & 2-Furanmethanol & $\mathrm{C} 5 \mathrm{H} 6 \mathrm{O} 2$ & 98 & 2.83 \\
\hline 2 & 21,551 & 1H-Cyclopropaanaphthalene & $\mathrm{C} 15 \mathrm{H} 24$ & 204 & 1.40 \\
\hline 3 & 22,514 & Trans-caryophyllene & $\mathrm{C} 15 \mathrm{H} 24$ & 204 & 1.03 \\
\hline 4 & 22,874 & Cyclohexane & $\mathrm{C} 13 \mathrm{H} 20$ & 176 & 2.13 \\
\hline 5 & 23,402 & Caryophyllene & $\mathrm{C} 15 \mathrm{H} 24$ & 204 & 1.11 \\
\hline 6 & 23,402 & Sativen & $\mathrm{C} 15 \mathrm{H} 24$ & 204 & 1.87 \\
\hline 7 & 23,794 & Delta-guaiene & $\mathrm{C} 15 \mathrm{H} 24$ & 204 & 2.43 \\
\hline 8 & 24,695 & Tetradecanoic acid & $\mathrm{C} 15 \mathrm{H} 30 \mathrm{O} 2$ & 242 & 1.40 \\
\hline 9 & 32,500 & Octadecanal & $\mathrm{C} 18 \mathrm{H} 36 \mathrm{O}$ & 268 & 5.59 \\
\hline 10 & 33,428 & 3-Eicosyne & $\mathrm{C} 20 \mathrm{H} 38$ & 278 & 4.75 \\
\hline 11 & 34,402 & Octadecanoic acid & C19H38 O2 & 298 & 22.93 \\
\hline 12 & 35,784 & Octadecanoic acid & $\mathrm{C} 20 \mathrm{H} 40 \mathrm{O} 2$ & 312 & 5.95 \\
\hline 13 & 36,444 & Octadecanoic acid & C19H38 O2 & 298 & 1.52 \\
\hline 14 & 37,792 & 9,12-Octadecadienoic acid & С19H34 O2 & 294 & 5.06 \\
\hline 15 & 37,921 & 9,12-Octadecadienoic acid & $\mathrm{C} 19 \mathrm{H} 34 \mathrm{O} 2$ & 294 & 14.99 \\
\hline 16 & 38,414 & Octadecanoic acid & C19H38 O2 & 298 & 7.59 \\
\hline 17 & 39,184 & 9-Hexadecenoic acid & $\mathrm{C} 16 \mathrm{H} 30 \mathrm{O} 2$ & 254 & 6.17 \\
\hline 18 & 39,304 & 1-Hexadecanol & $\mathrm{C} 16 \mathrm{H} 34 \mathrm{O}$ & 242 & 4.08 \\
\hline 19 & 39,668 & Hexadecenoic acid & $\mathrm{C} 18 \mathrm{H} 36 \mathrm{O} 2$ & 284 & 1.99 \\
\hline 20 & 40,034 & 11-Tetradecen-1-ol & $\mathrm{C} 16 \mathrm{H} 30 \mathrm{O} 2$ & 254 & 2.92 \\
\hline 21 & 49,859 & 3,7,11-Tridecatrienenitrile & $\mathrm{C} 16 \mathrm{H} 25 \mathrm{~N}$ & 231 & 1.20 \\
\hline 22 & 54,548 & $2 \mathrm{H}-\mathrm{Pyran}$ & $\mathrm{C} 22 \mathrm{H} 40 \mathrm{O} 2$ & 336 & 1.07 \\
\hline
\end{tabular}

2.2. Malacca Leaf Sample Preparation. The extraction was carried out at Pharmacology Laboratory, Faculty of Veterinary Medicine, Syiah Kuala University. Malacca leaf samples were dried for several days, and then $1.5 \mathrm{~kg}$ dried samples were mashed to form simplisia. Simplisia was put into Erlenmeyer and then added with 1 liter of n-hexane. The maceration of simplisia was carried out for three days, and stirring was done infrequently. Subsequently, the maceration solution was filtered using the filter paper, and then the precipitate of simplisia was added with ethyl acetate followed by the maceration process for three days and filtration of the residue. The third maceration was performed using ethanol for three days, filtered, and dried using an evaporator until reaching paste-like texture.

2.3. Identification of Chemical Compounds by Using Gas Chromatography-Mass Spectrophotometer. Gas chromatography-mass spectrophotometer (GC-MS) used was GCMS-QP2010S SHIMADZU consisting of the AOC-20i autosampler and gas chromatography connected to mass spectrometer instruments (GC-MS) using the following conditions: Restek RtxR-5 (30 meters $\times 0.25 \mathrm{~mm}) \quad(5 \%$ diphenyl and $95 \%$ dimethyl polysiloxane) runs in the electron impact mode at $70 \mathrm{eV}$; helium (99.99\%) was used as a carrier gas at a constant flow of $1 \mathrm{ml} /$ minute, and an injection volume of $1.0 \mu \mathrm{l}$ was used (split ratio $10: 1$ ); and $300^{\circ} \mathrm{C}$ injector temperature. The oven temperature was programmed from $70^{\circ} \mathrm{C}$ (isothermal for 5 minutes), with an increase of $6^{\circ} \mathrm{C} /$ minute to $280^{\circ} \mathrm{C}$ and then terminated with isothermal for 15 minutes at $280^{\circ} \mathrm{C}$. The mass spectrum was taken at $70 \mathrm{eV} ; 0.5$ second scanning interval; and fragments from 40 to $550 \mathrm{Da}$. The total running time of $\mathrm{GC}$ is 60 minutes.
The peaks that appear on the GC-MS screen were interpreted using the National Institute of Standard and Technology (NIST) database. The mass spectrum of unknown components was compared to the spectrum of known components stored in the NIST library.

\section{Results and Discussion}

Malacca leaf samples were collected from the Malacca plant which grew in Blang Thutu, Lambirah Village of Aceh Besar district (Figure 1).

The chemical compounds of the ethanolic extract of the Malacca leaf identified using GC-MS can be seen in Figure 2. Structural analysis of organic compounds spectroscopically included using a mass spectrum to determine the molecular formula and to determine the mass of a molecule [24]; in addition to GCMS, there is also an infrared spectrophotometer to determine the functional group of a compound [25]. There were 22 chemical compounds identified, and the most abundant compound in the Malacca ethanolic extract of Malacca leaves was decanoic acid (22.93\%).

Octadecanoic acid was detected at 34.4 minutes in the ethanol extract of Malacca leaves and has another name stearic acid which has 18 carbon atom chain and saturated fatty acid that has a carbon backbone and consists of a long chain of carbon atoms bonded together by single bonds and with 2 hydrogen atoms attached to each internal carbon atom. The second largest compound detected at minute 37.9 was 9,12-octadecadinoic acid (14.99\%). The third most detected compound at minute 38.4 was octadecanoic acid (7.59\%), and the next minute was 9-hexadecenoic acid (6.17\%), octadecanoic acid (5.95\%), octadecanal (5.59\%), 9,12-octadecanoic acid (5.06\%), 3-eicosyne (4.75\%), 1hexadecenoic acid (4.08\%), 11-tetradecen-1-ol (2.92\%), 2furanmethanol $(2.83 \%)$, delta-guaiene $(2.43 \%)$, cyclohexane 
(2.13\%), hexadecenoic acid (1.99\%), sativen (1.87\%), octadecanoic acid (1.52\%), $1 \mathrm{H}$-cyclopropaanaphthalene (1.40\%), tetradecanoic acid (1.40\%), 3,7,11-tridecatrienenitrile $(1.20 \%)$, caryophellene $(1.11 \%), 2 \mathrm{H}$-pyran $(1.07 \%)$, and minute 23.4 found trans-caryophellene (1.03\%) (Table 1).

Some types of medicinal plants that contain a lot of fatty acids are very good as antioxidants and antimalarial. The active ingredients detected have very little detailed information available explaining the function of each of them. Another name for tetradecanoic acid is myristic acid, the dodecanoic acid synonym is lauric acid, and the synonym of octadecanoic acid is stearic acid; the whole chemical component is included in the group of saturated fatty acids [26].

\section{Conclusions}

The GC-MS analysis of the Malacca leaf extract (Phyllanthus emblica) clearly shows the presence of fatty acids which are mainly found in the leaf. There were 22 chemical compounds identified, and the most abundant compound in the Malacca ethanolic extract of Malacca leaves was decanoic acid (22.93\%). These chemical constituents play a major role in the efficacy of these traditional medicines particularly as antioxidants and antimalarial. The study also showed that many other phytochemical compounds have not been tested for their biological activity. Therefore, further research is needed to be carried out on the application of these phytochemical compounds in pharmaceutical fields.

\section{Data Availability}

The data used to support the findings of this study are available from the corresponding author upon request.

\section{Conflicts of Interest}

The authors declare no conflicts of interest.

\section{Acknowledgments}

The authors wish to thank the Pharmacology Laboratory, Faculty of Veterinary Medicine, Universitas Syiah Kuala, for the allocation of facilities during this study. This research was funded by Directorate of Research and Community Service Higher Education, no. 105/ADD/SP2HL/LT/DPRM/ VIII/2017.

\section{References}

[1] T. Uji, "Review: keanekaragaman jenis buah-buahan asli Indonesia dan potensinya," Pusat Penelitian Biologi-LIPI, vol. 8, no. 2, pp. 157-167, 2006.

[2] S. Sunarti, Keanekaragaman Tumbuhan Berkhasiat Obat di Pulau Moti, Ternate, Dan Maluku Utara, Puslit Biologi LIPI, Bogor, Indonesia, 2011.

[3] T. Yulistyarini, E. E. Ariyanti, and N. D. dan Yulia, "Jenis-jenis tanaman buah yang bermanfaat untuk usaha konservasi lahan kering," in Prosiding Seminar Hari Cinta Puspa dan Satwa Nasional, Kebun Raya Purwodadi- LIPI, Pasuruan, Indonesia, 2000.
[4] U. Khoiriyah, N. Pasaribu, and S. Hannum, "Distribusi phyllanthus emblica L. di Sumatera Utara bagian selatan," Biosfera, vol. 32, no. 2, pp. 98-102, 2015.

[5] D. G. Nayaka, "Propagation studies in aonla (Phyllanthus emblica L.)," Thesis, Department of Horticulture College of Agriculture. University of Agricultural Sciences, Dharwad, India, 2006.

[6] J. Charoenteeraboon, C. Ngamkiidechakul, N. Doonthornchareonnon, K. Jaijoy, and S. Sireeratawong, "Antioxidant activities of the standardized water extract from fruit of Phyllanthus emblica Linn," Songklanakarin Journal of Science and Technology, vol. 32, no. 6, pp. 599-604, 2010.

[7] J. O. Summanen, A Chemical and Ethnopharmacological Study on Phyllanthus Emblica (Euphorbiaceae), Departement of Pharmacy University of Helsinki, Helsinki, Finland, Academic Dissertation, 1999.

[8] S. Khatoon, V. Rai, A. K. S. Rawat, and S. Mehrotra, "Comparative pharmacognostic studies of three Phyllanthus species," Journal of Ethnopharmacology, vol. 104, no. 1-2, pp. 79-86, 2006.

[9] M. B. Manali and S. A. Nitave, "Roles of Emblica officinalis (amla) in medicine," World Journal of Pharmaceutical Sciences, vol. 3, no. 6, pp. 604-615, 2014.

[10] D. W. Unander, G. L. Webster, and B. S. Blumberg, "Usage and bioassays in Phyllanthus (Euphorbiaceae). IV. Clustering of antiviral uses and other effects," Journal of Ethnopharmacology, vol. 45, no. 1, pp. 1-18, 1995.

[11] E. Singh, S. Sharma, A. Pareek, J. Dwivedi, S. Yadav, and S. Sharma, "Phytochemistry, traditional uses and cancer chemopreventive activity of amla (Phyllanthus emblica): the sustainer," Journal of Applied Pharmaceutical Science, vol. 2, no. 1, pp. 176-183, 2011.

[12] B. P. James, S. K. Sharma, A. Joseph, and A. J. M. Christina, "Evaluation of antipyretic and analgesic activity of Emblica officinalis Gaertn," Journal of Ethnopharmacology, vol. 95, no. 1, pp. 83-85, 2004.

[13] C. Ngamkitidechakul, K. Jaijoy, P. Hansakul, N. Soonthornchareonnon, and S. Sireeratawong, "Antitumour effects of Phyllanthus emblica L.: induction of cancer cell apoptosis and Inhibition of in vivo tumour promotion and in vitro invasion of human cancer cells," Phytotherapy Research, vol. 24, no. 9, pp. 1405-1413, 2010.

[14] D. Sumalatha, "Antioxidant and antitumor activity of Phyllanthus emblica in colon cancer cell lines," International Journal of Current Microbiology and Applied Sciences, vol. 2, no. 5, pp. 189-195, 2013.

[15] E. Nicolis, I. Lampronti, M. C. Dechecchi et al., "Pyrogallol, an active compound from the medicinal plant Emblica officinalis, regulates expression of pro-inflammatory genes in bronchial epithelial cells," International Immunopharmacology, vol. 8, no. 12, pp. 1672-1680, 2008.

[16] G. K. Dang, R. R. Parekar, S. K. Kamat, A. M. Scindia, and N. N. Rege, "Antiinflammatory activity of Phyllanthus emblica, Plumbago zeylanica and Cyperus rotundus in acute models of inflammation," Phytotherapy Research, vol. 25, no. 6, pp. 904-908, 2011.

[17] S. A. Qureshi, W. Asad, and V. Sultana, "The effect of Phyllantus emblica Linn on type - II diabetes, triglycerides and liver-specific enzyme," Pakistan Journal of Nutrition, vol. 8, no. 2, pp. 125-128, 2009.

[18] S. M. Khopde, K. Indira Priyadarsini, and H. Mohan, "Characterizing the antioxidant activity of amla (Phyllanthus emblica) extract," Current Science, vol. 81, pp. 185-190, 2001.

[19] N. E. Malliga, M. S. Dhanarajan, and I. Elangovan, "Evaluation of antibacterial and antifungal activity of Phyllanthus 
emblica leaf extract," International Research Journal of Pharmaceutical and Biosciences.vol. 2, no. 2, pp. 59-66, 2015.

[20] N. Singh, C. Mathur, N. A. Sase, S. Rai, and J. Abraham, "Pharmaceutical properties of Emblica officinalis and Phyllanthus emblica extracts," Research Journal of Pharmaceutical, Biological and Chemical Sciences, vol. 6, no. 1, pp. 1007-1016, 2015.

[21] H. L. V. Malar and S. Mary, "Hepato-protective activity of Phyllanthus emblica against paracetamol induced hepatic damage in wister albino rats," African Journal of Basic and Applied Sciences, vol. 1, no. 1-2, pp. 21-25, 2009.

[22] N. Asmilia, D. Aliza, J. Melia, E. Rahmi, and L. S. M. Daulay, "The effect of malacca leaves (Phyllantus emblica) ethanolic extract on Plasmodium falciparum growth in vitro," Jurnal Kedokteran Hewan, Indonesian Journal of Veterinary Sciences, vol. 12, no. 4, 2018.

[23] P. Deepak and G. V. Gopal, "GC-MS analysis of ethyl acetate extract of Phyllanthus emblica L. bark," British Biomedical Buletin, vol. 2, no. 2, pp. 285-292, 2014.

[24] Dachriyanus, Analisis Struktur Senyawa Organik Secara Spektroskopi, Andalas University Press, Padang, Indonesia, 2004.

[25] N. Rekik, A. Velcescu, P. Blaise, and O. H. Rousseau, "Spectral density of H-bonds. II. Intrinsic anharmonicity of the fast mode within the strong anharmonic coupling theory," Chemical Physics, vol. 273, no. 1, pp. 11-13, 2001.

[26] Anonimous, "Myristic acid," 2008, https://pubchem.ncbi. nlm.nih.gov/compound/Myristic-acid. 